\title{
Experimental Study on Behavior of Bow-tie Tree Generation by Using Heavy Water
}

\author{
Takao Kumazawa Member (Chubu Electric Power Co., Inc.) \\ Wataru Nakagawa Member (Tatsuta Electric Wire \& Cable Co., Ltd.) \\ Hidekazu Tsurumaru Member (Tatsuta Electric Wire \& Cable Co., Ltd.)
}

Keywords : XLPE cable, water tree, bow-tie tree, deterioration, heavy water, isotopic effect

Bow-tie tree (BTT) generated from contaminant, e.g., metal, carbon, amber (over cured resin) or void in insulator is a deterioration factor of XLPE power cable. However, essential role of water in generation and progress of BTT is not yet sufficiently cleared. In order to investigate the role of water we paid attention to difference in chemical properties of light water $\left(\mathrm{H}_{2} \mathrm{O}\right)$ and heavy water $\left(\mathrm{D}_{2} \mathrm{O}\right)$, moreover we evaluated influence of isotopic effect due to hydrogen and deuterium on behavior of BTT generation.

Fig. 1 shows configuration of accelerated aging test. XLPE samples, in which copper powder of 500ppm was contaminated as BTT cores, were dipped in light water mixed with $0,1,10$ or $100 \mathrm{wt} \%$ of heavy water. A cell for voltage application using separable beaker was immersed in tap water maintained at $60^{\circ} \mathrm{C}$, and $\mathrm{AC}$ electric field $(2 \mathrm{kV} / \mathrm{mm}, 2400 \mathrm{~Hz})$ was applied to XLPE sample for 240 hours.

Fig. 2 shows relation between size of BTT cores and length of BTT in XLPE samples after accelerated aging test in various concentrations of $\mathrm{D}_{2} \mathrm{O}$. The number of BTT in XLPE sample dipped in heavy water $\left(\mathrm{D}_{2} \mathrm{O}: 100 \mathrm{wt} \%\right)$ decreased to one third compared with light water $\left(\mathrm{D}_{2} \mathrm{O}: 0 \mathrm{wt} \%\right)$. Furthermore, the maximum length of BTT decreased with increase in concentration of $\mathrm{D}_{2} \mathrm{O}$. The experimental results show that heavy water exerted a

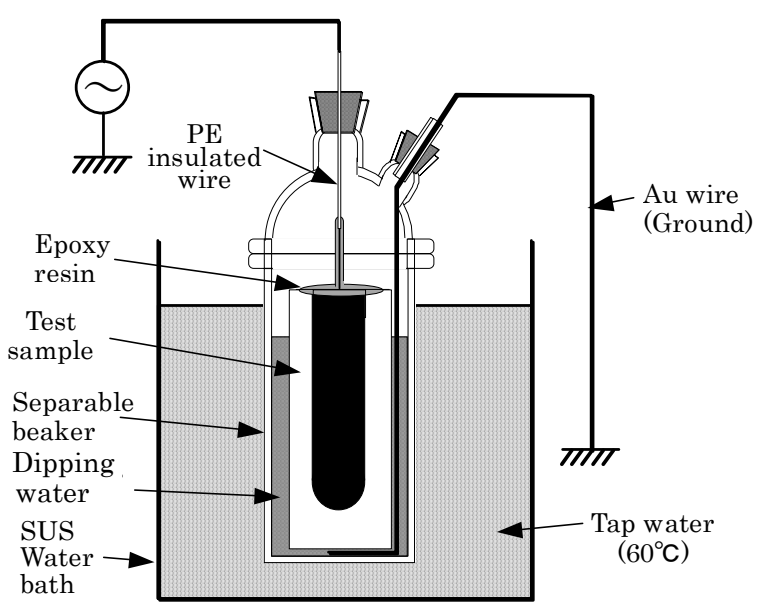

Fig. 1. Configuration of accelerated aging test. depression effect on generation and progress of BTT. There was, however, no difference in shape of BTT using light water and heavy water.

From these results we considered that the depression effect due to hydrogen isotope appeared by inhibiting ionization and elution of BTT cores, because salt-solubility and ionic mobility of heavy water are about 15 to $20 \%$ smaller than those of light water. Therefore, the essential role of water seemed to be production and transport of ions in XLPE.

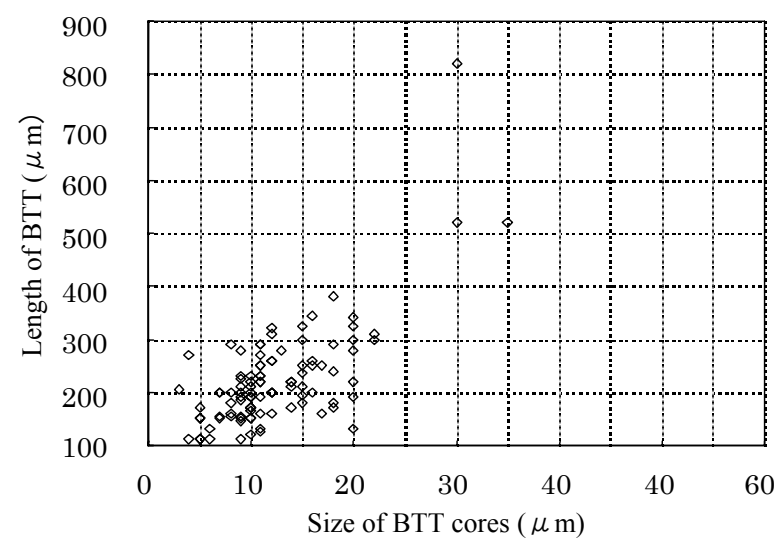

(a) $\mathrm{D}_{2} \mathrm{O}: 0 \mathrm{wt} \%$ (demineralized light water)

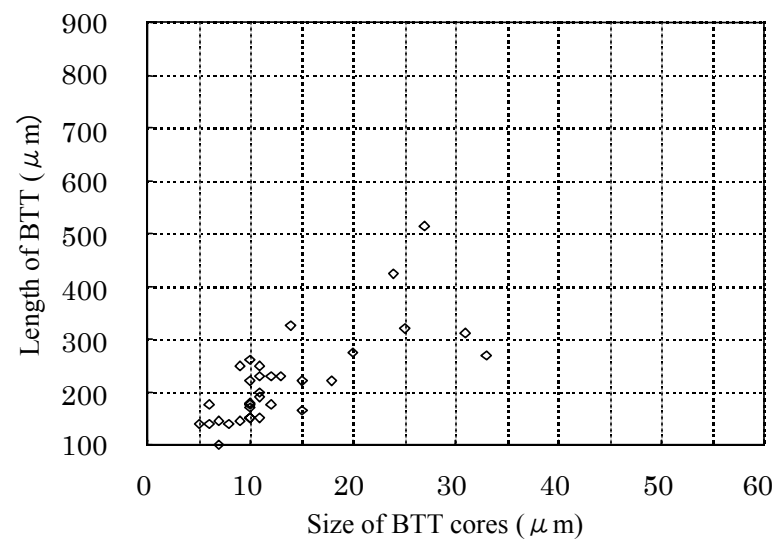

(b) $\mathrm{D}_{2} \mathrm{O}: 100 \mathrm{wt} \%$

Fig. 2. Relation between size of BTT cores and length of BTT in various concentration of $\mathrm{D}_{2} \mathrm{O}$. 


\title{
重水を用いたボウ・タイ状水トリーの発生挙動に関する実験的考察
}

\author{
正員 熊澤 孝夫* 正 員 中川 渡** \\ 正 員 鶴丸 秀一**
}

\section{Experimental Study on Behavior of Bow-tie Tree Generation by Using Heavy Water}

Takao Kumazawa*, Member, Wataru Nakagawa**, Member, Hidekazu Tsurumaru**, Member

\begin{abstract}
Bow-tie tree (BTT) generated from contaminant, e.g., metal, carbon, amber(over cured resin) or void in insulator is a significant deterioration factor of XLPE power cable. However, essential role of water in generation and progress of BTT is not yet sufficiently cleared. In order to investigate the role of water we paid attention to difference in chemical properties of light water $\left(\mathrm{H}_{2} \mathrm{O}\right)$ and heavy water $\left(\mathrm{D}_{2} \mathrm{O}\right)$, moreover we evaluated influence of isotopic effect due to hydrogen and deuterium on behavior of BTT generation. In accelerated aging test the number of BTT in XLPE sample, in which copper powder of 500ppm was contaminated as BTT cores, dipped in heavy water $\left(\mathrm{D}_{2} \mathrm{O}: 100 \mathrm{wt} \%\right)$ decreased to one third compared with light water $\left(\mathrm{D}_{2} \mathrm{O}: 0 \mathrm{wt} \%\right)$. Furthermore, the maximum length of BTT decreased with increase in concentration of heavy water. The experimental results show that heavy water exerted a depression effect on generation and progress of BTT. We considered that the depression effect due to hydrogen isotope appeared by inhibiting ionization and elution of BTT cores, because salt-solubility and ionic mobility of heavy water are about 15 to $20 \%$ smaller than those of light water. Therefore, the essential role of water seemed to be production and transport of ions in XLPE.
\end{abstract}

キーワード：CVケーブル, 水トリー, ボウ・タイ状水トリー, 劣化, 重水, 同位体効果

Keywords : XLPE cable, water tree, bow-tie tree, deterioration, heavy water, isotopic effect

\section{1. まえがき}

$\mathrm{CV}$ ケーブルの絶縁体中の微小な異物やボイド等を発生 起点とするボウ・タイ状水トリー（以下，BTTと略記）は， 依然として重要な寿命決定因子の一つとなっている(1) (3)。 BTT の発生・進展メカニズムについては, 架橋ポリエチレ ン $(\mathrm{XLPE})$ 中の水分量が無課電時の飽和水分量に達したと きにBTTの発生数が急増するとして，水分の凝集・液化に 基づいたモデルが提案されている(4)。このモデルでは, XLPE 中に飽和水蒸気として存在するガス状の水分が異物 近傍の電界集中部で凝集・液化し, 高圧力の噴流となって 分子鎖切断に至ると考えられている(4)。そのほかに，近年で は水トリー劣化部においてカルボニル化合物等の酸化生成 物が観測されており，不純物として存在する金属イオンの 触媒作用により XLPE が酸化・分子鎖切断に至るとする化

\footnotetext{
* 中部電力 (株) 技術開発本部 電力技術研究所

干 459-8522 名古屋市緑区大高町字北関山 20-1

Chubu Electric Power Co.,Inc. Electric Power R\&D Center

20-1, Kitasekiyama Ohdaka, Midori-ku, Nagoya 459-8522

** タツタ電線 (株)

干578-8585 東大阪市岩田町 2-3-1

Tatsuta Electric Wire\&Cable Co.,Ltd.

2-3-1, Iwata-cho, Higashi-Osaka 578-8585
}

学的な発生・進展機構も考えられている(5)(6)。

このように水分の役割については，いわゆる “主役” か “脇役”かによって仮説が明確に分かれることから，著者ら は様々な実験を通して水分やイオンの本質的な役割につい て考察を進めてきた。これまでに，XLPE 試料を浸漬した 水溶液が蒸発・揮散する開放系課電と蒸発・揮散しない密 閉系課電, 或いは間久浸漬課電と連続浸漬課電といった環 境の違いによる BTTの発生挙動の変化を詳しく観察した。 既に報告(7) したように, 課電前後における試料の水分量の変 化と BTT の発生数との間には因果関係が見いだせず，従来 の水分の凝集・液化に基づくモデルでは実験結果を十分に 説明することが困難であった。また, BTT の発生には XLPE 内部のイオンが方向性を持った運動をしており，その運動 がある程度持続するような環境が必要と考えられた。

そこで今回は水が有する基本的な性質に着目し，その振 る舞いをより鮮明に観察すべく新たな実験を行った。すな わち，所定の濃度に調整した軽水 $\left(\mathrm{H}_{2} \mathrm{O}\right)$ と重水 $\left(\mathrm{D}_{2} \mathrm{O}\right)$ の 混合液体に XLPE 試料を浸漬して BTT を発生させ, それぞ れの液体が有する化学的性質の違いが BTTの発生によ゙のよ うな影響を及ぼすかを調査した。この実験においては重水 
の BTT 抑制効果が認められたため, その原因を推定しなが ら水分の本質的な役割について考察した。

\section{2. 実験方法}

〈2·1〉 試 料 CV ケーブルの絶縁体に混入する可 能性がある微小異物の一つにメタル（導体金属の粉体等） がある。今回は入手が容易な工業用の銅粉を用いてこれを 模擬し，BTTの発生核とした。表 1 に銅粉の大きさと形状 を，図 1 に銅粉の粒径分布をそれぞれ示す。銅粉はほぼ球 形で，平均直径は $30.7 \mu \mathrm{m}$ である。小型ミキサーと熱ロー ルにより，この銅粉を XLPE 中に 500ppm 添加・混練し， 図 2 に示寸形状のサンドイッチシートをプレス成型により 作製して試料とした。また架橋剤の分解残渣ならびに水分 を取り除くため, 全ての試料に予め熱処理 $\left(90^{\circ} \mathrm{C}\right.$ 雰囲気に 48 時間放置) を施し, 初期水分量を $5 \mathrm{ppm}$ 未満に調整した。

$\langle 2 \cdot 2\rangle$ 課電方法 試料の浸漬には軽水と重水の混合 液体を用い，重水の濃度は $0 \mathrm{wt} \%$ （自然界では軽水中にも 約 0.015wt\%含まれる)，1 wt\%，10wt\%および 100wt\%の 4 水準とした。混合液体に使用した軽水は全てイオン交換水 である。

軽水と重水の混合液体においては水素 $(\mathrm{H})$ と重水素 (D) の同位体交換反応が速やかに起きるため，課電期間中は実 質的に平衡状態に達していると推察される。このとき, $\mathrm{D}_{2} \mathrm{O}$ を $1 \mathrm{wt} \%$ 混合した場合はその殆どが HDO として存在し，

表 1 BTT の発生核

Table 1. Size and shape of BTT core.

\begin{tabular}{|c|c|c|c|c|}
\hline Core & $\begin{array}{c}\text { Particle } \\
\text { size } \\
(\mu \mathrm{m})\end{array}$ & $\begin{array}{c}\text { Content } \\
(\mathrm{ppm})\end{array}$ & $\begin{array}{c}\text { Particle } \\
\text { density } \\
\left(\mathrm{N} / \mathrm{mm}^{3}\right)\end{array}$ & Note \\
\hline $\begin{array}{c}\text { Copper } \\
\text { powder }\end{array}$ & $\begin{array}{c}7 \sim 116^{*} \\
(\text { Median } \\
\text { D.: 30.7) }\end{array}$ & 500 & $\sim 11.3$ & \\
\hline
\end{tabular}

* Laser scattering particle-size/ - distribution analyzer

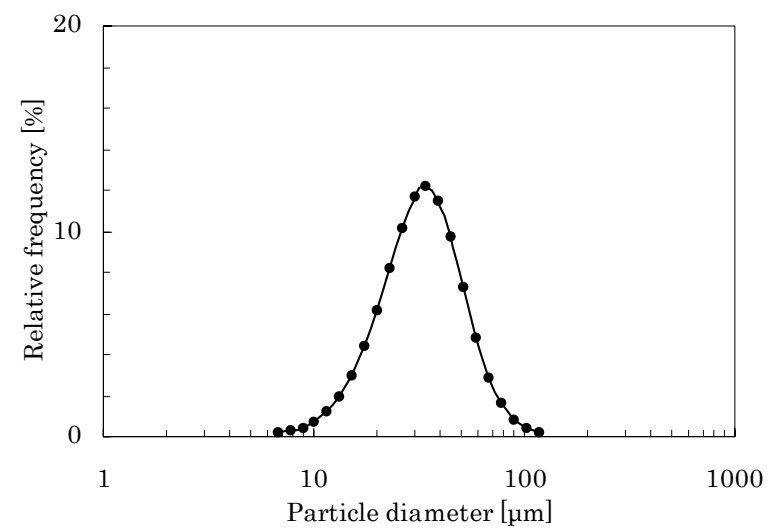

図 1 銅粉の粒径分布

Fig. 1. Distribution of particle diameter in copper powder. 10wt\%混合した場合には， $\mathrm{H}_{2} \mathrm{O}, \mathrm{HDO}, \mathrm{D}_{2} \mathrm{O}$ の mol 比は 概略 $80: 18: 2$ となっている(8)。

電極配置については, 図 3 に示すような密閉系課電(7) とし た。この課電方法は浸漬水の蒸発・揮散が起きないため, 重水素の量をほぼ一定に保つことができる。セッティング の手順として，まずセパラブルビーカー内に上記の混合液 体を注入して試料を浸漬した後, セパラブルカバーを被せ た。次にこれを水道水で満たした SUS 製ウォーターバス内 にセットし, 最後にウォーターバス内の水道水を $60^{\circ} \mathrm{C}$ に保 持しながら，試料に $2,400 \mathrm{~Hz} ， 2 \mathrm{kV} / \mathrm{mm}$ の電界を 240 時間 印加した。

〈2·3〉試料の観察 図 4 に BTT 観察用試料片の採取 方法を示す。まず， BTT 発生部分(平等電界部)から観察体 積が一定 (約 $1020 \mathrm{~mm}^{3}$ ) になるように切り出し, これを

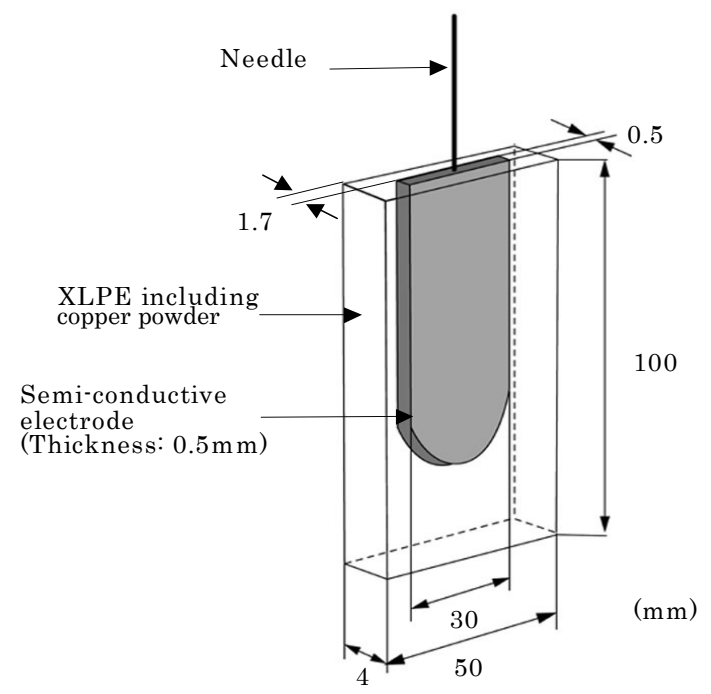

図 2 試料の形状

Fig. 2. Construction of XLPE sample for accelerated aging.

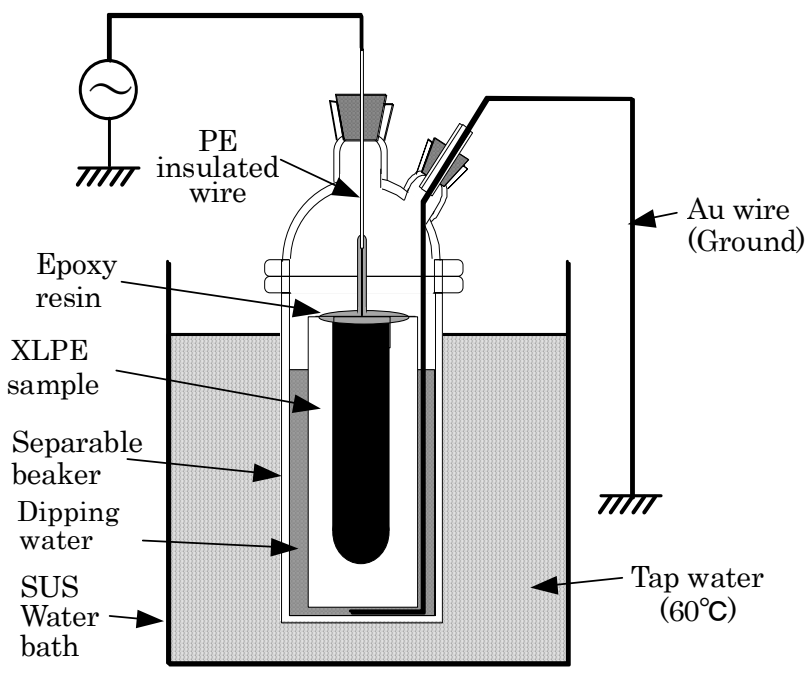

図 3 加速劣化試験の電極配置

Fig. 3. Configuration of accelerated aging test. 
表 2 加速劣化試験後の BTT の発生数と最大伸び

Table 2. Number and maximum length of BTT after accelerated aging test.

\begin{tabular}{|c|c|c|c|c|c|c|}
\hline \multirow{2}{*}{$\begin{array}{l}\text { Concentration of } \mathrm{D}_{2} \mathrm{O} \\
(\mathrm{wt} \%)\end{array}$} & \multicolumn{2}{|c|}{ Water content } & \multirow{2}{*}{$\begin{array}{l}\text { Number } \\
\text { of cores } \\
\left(\mathrm{N} / \mathrm{mm}^{3}\right)\end{array}$} & \multicolumn{3}{|c|}{ BTT } \\
\hline & \begin{tabular}{|c|}
$\begin{array}{c}\text { Before aging } \\
(\mathrm{ppm})\end{array}$ \\
\end{tabular} & $\begin{array}{c}\text { After aging } \\
(\mathrm{ppm})\end{array}$ & & $\begin{array}{c}\text { Number } \\
(\mathrm{N})\end{array}$ & $\begin{array}{l}\text { Generating } \\
\text { ratio (\%) }\end{array}$ & $\begin{array}{c}\text { Maximum } \\
\text { length }(\mu \mathrm{m})\end{array}$ \\
\hline 0 & \multirow{3}{*}{$<5$} & 37 & \multirow{3}{*}{$\sim 11.3$} & 100 & 8.7 & 820 \\
\hline 10 & & 42 & & 120 & 10.4 & 420 \\
\hline 100 & & 65 & & 34 & 2.9 & 515 \\
\hline
\end{tabular}

Volume of observation : $1020 \mathrm{~mm}^{3}$, Length of observation on BTT and VT : $\geqq 100 \mu \mathrm{m}$

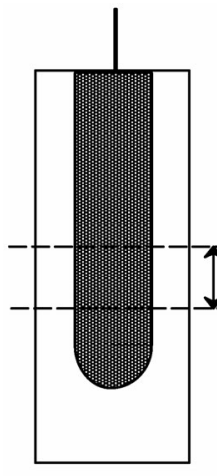

Cut off

(10 $\mathrm{mm}$ thickness)
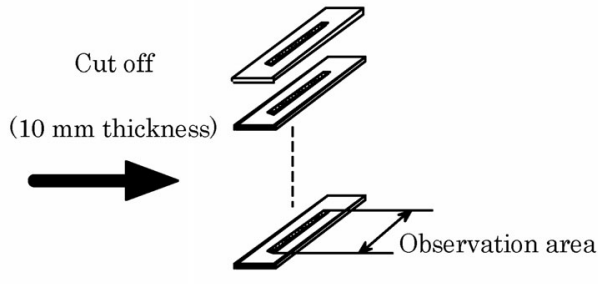

- Slice (0.5mm thickness)

- Observation volume : $1020 \mathrm{~mm}^{3}$

図 4 BTT 観察用試料片の採取方法

Fig. 4. Collecting method of sample for BTT observation.

$0.5 \mathrm{~mm}$ 厚にスライスした後, クリスタルバイオレット溶液 で煮沸染色した。この試料片について, 光学顕微鏡により $100 \mu \mathrm{m}$ 以上の BTT を観察した。また, 試料の水分量を力 ールフィッシャー法により測定した。

\section{3. 結果および考察}

〈3.1〉 BTTの観察結果 図5に観察した BTTの代表 例を示す。BTT の外観は軽水と重水で特に違いは見られず, 形状に関しては水素の同位体の影響は現れていない。

表 2 にBTT の観察結果の一覧を示す。また, 図 6 に BTT 発生核の大きさと伸びの関係を重水の濃度別に示す。BTT の発生率は，重水の濃度に対する明確な相関性が見られな いものの, 100wt\%では 0wt\%の 1/3 (=2.9/8.7) に減少して いる点は注目される。発生核の大きさに関しては，いずれ の重水濃度においても $5 \sim 20 \mu \mathrm{m}$ 程度の銅粉からの発生が 顕著である。図 1 に示した銅粉の粒径分布から，この範囲 の大きさの銅粉が占める割合は約 $18 \%$ となるが，これより も大きな銅粉は圧倒的に多いにもかかわらず BTT の発生は 非常に少なかった。他方, BTT の最大伸びは, 重水の濃度 が増加するにつれて鈍化する傾向が見られる。ただし, BTT 発生核の大きさと伸びの関係については，いずれの重水濃 度においても BTT が多発する銅粉の大きさ（5～20 $\mu \mathrm{m}$ 程 度）とそれに対応する BTT の伸び（概ね $100 〜 400 \mu \mathrm{m}$ ） に明確な差はなく，したがって相関性には顕著な違いは見 られない。総じて軽水／重水混合系においてはBTT の重水 濃度依存性が不明瞭であったが，その原因としては混合し

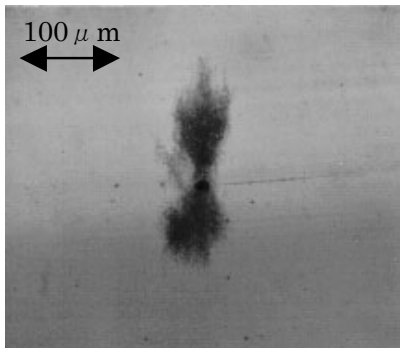

(a) $\mathrm{D}_{2} \mathrm{O}: 0 \mathrm{wt} \%$

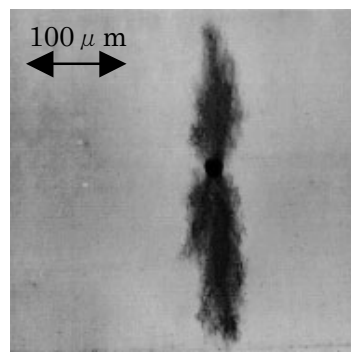

(b) $\mathrm{D}_{2} \mathrm{O}: 100 \mathrm{wt} \%$
図 5 BTT 観察結果の一例

Fig. 5. Typical result of BTT observation.

表 3 軽水と重水の化学的性質の比較

Table 3. Comparison of chemical properties of $\mathrm{H}_{2} \mathrm{O}$ and $\mathrm{D}_{2} \mathrm{O}$.

\begin{tabular}{|c|c|c|c|}
\hline \multicolumn{2}{|c|}{ Chemical property } & $\mathrm{H}_{2} \mathrm{O}$ & $\mathrm{D}_{2} \mathrm{O}$ \\
\hline Lattice constant $[\AA]$ & $\begin{array}{l}\mathrm{a} \\
\mathrm{c}\end{array}$ & $\begin{array}{l}4.514 \\
7.352\end{array}$ & $\begin{array}{l}4.517 \\
7.354\end{array}$ \\
\hline $\begin{array}{l}\text { Melting point }\left[{ }^{\circ} \mathrm{C}\right] \\
\text { at } 760 \mathrm{~mm} \mathrm{Hg}\end{array}$ & & 0.0 & 3.82 \\
\hline $\begin{array}{l}\text { Boiling point }\left[{ }^{\circ} \mathrm{C}\right] \\
\text { at } 760 \mathrm{~mm} \mathrm{Hg}\end{array}$ & & 100 & 101.42 \\
\hline Specific gravity & $\mathrm{d}_{4}{ }^{25}$ & 0.99708 & 1.10714 \\
\hline $\begin{array}{l}\text { Heat of melting } \\
{[\mathrm{cal} / \mathrm{mol}]}\end{array}$ & & 1436 & 1520 \\
\hline $\begin{array}{l}\text { Heat of evaporation } \\
{[\mathrm{cal} / \mathrm{mol}]}\end{array}$ & & 9710 & 9969 \\
\hline $\begin{array}{l}\text { Dielectric constant } \\
\text { at } 0^{\circ} \mathrm{C}\end{array}$ & & 81.5 & 80.7 \\
\hline $\begin{array}{l}\text { Ionic product } \times 10^{14} \\
\text { at } 25^{\circ} \mathrm{C}\end{array}$ & & 1.0 & 0.16 \\
\hline $\begin{array}{l}\text { Ionic mobility } \\
\text { at } 18^{\circ} \mathrm{C}\end{array}$ & $\begin{array}{c}\mathrm{D}^{+}, \mathrm{H}^{+} \\
\mathrm{K}^{+} \\
\mathrm{Cl}^{-}\end{array}$ & $\begin{array}{c}315.2 \\
64.2 \\
65.2\end{array}$ & $\begin{array}{c}213.7 \\
54.5 \\
55.3\end{array}$ \\
\hline $\begin{array}{l}\text { Solubility }[\mathrm{g} / 100 \mathrm{~g}] \\
\text { at } 25^{\circ} \mathrm{C}\end{array}$ & $\begin{array}{l}\mathrm{NaCl} \\
\mathrm{BaCl}_{2}\end{array}$ & $\begin{array}{l}35.8 \\
35.7\end{array}$ & $\begin{array}{l}29.7 \\
28.9\end{array}$ \\
\hline
\end{tabular}

The source:Encyclopedia CHEMICA Vol.4, pp.650 (Kyoritsu)

た重水の濃度がやや低く, 殆どが HDO として存在したため と思われる。これに対して単一系（重水 $100 \mathrm{wt} \%$ または 0wt\%）においては，明らかに BTT の発生・進展に違いが 見られ，いわゆる水素の同位体効果が認められる。

なお，試料中の水分量に関しては，表 2 より重水の濃度 と共に増加する傾向が見られるが，この程度の変化であれ ば BTT の発生・進展に影響を及ぼすことは考え難い(7)。 

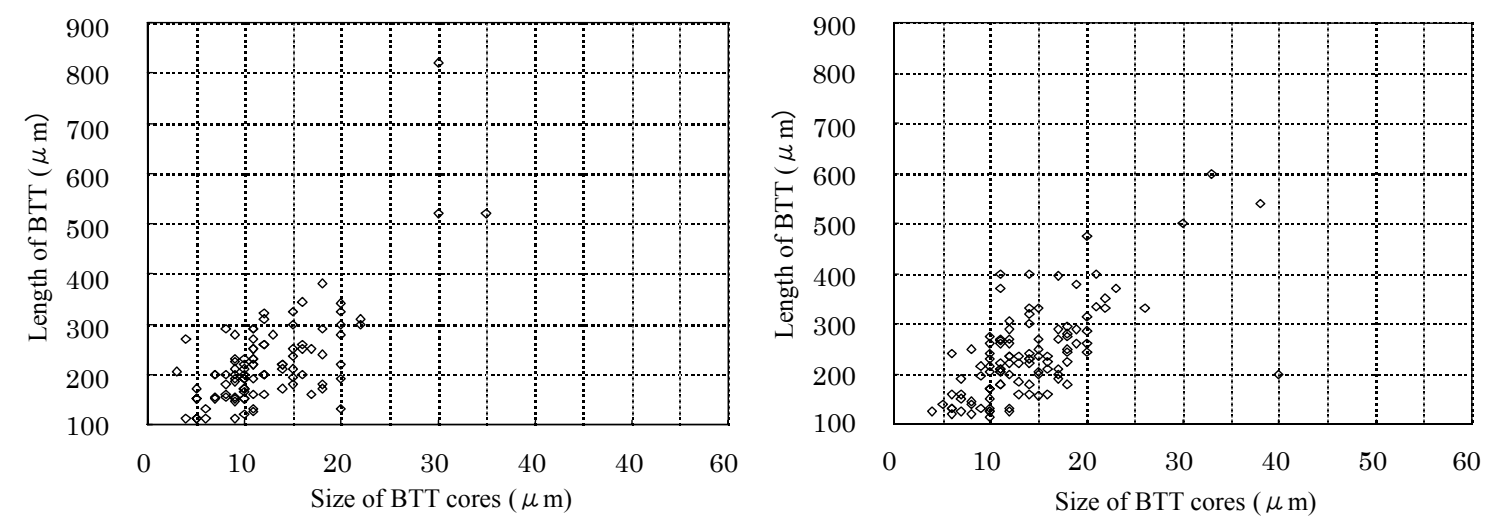

(a) $\mathrm{D}_{2} \mathrm{O}: 0 \mathrm{wt} \%$
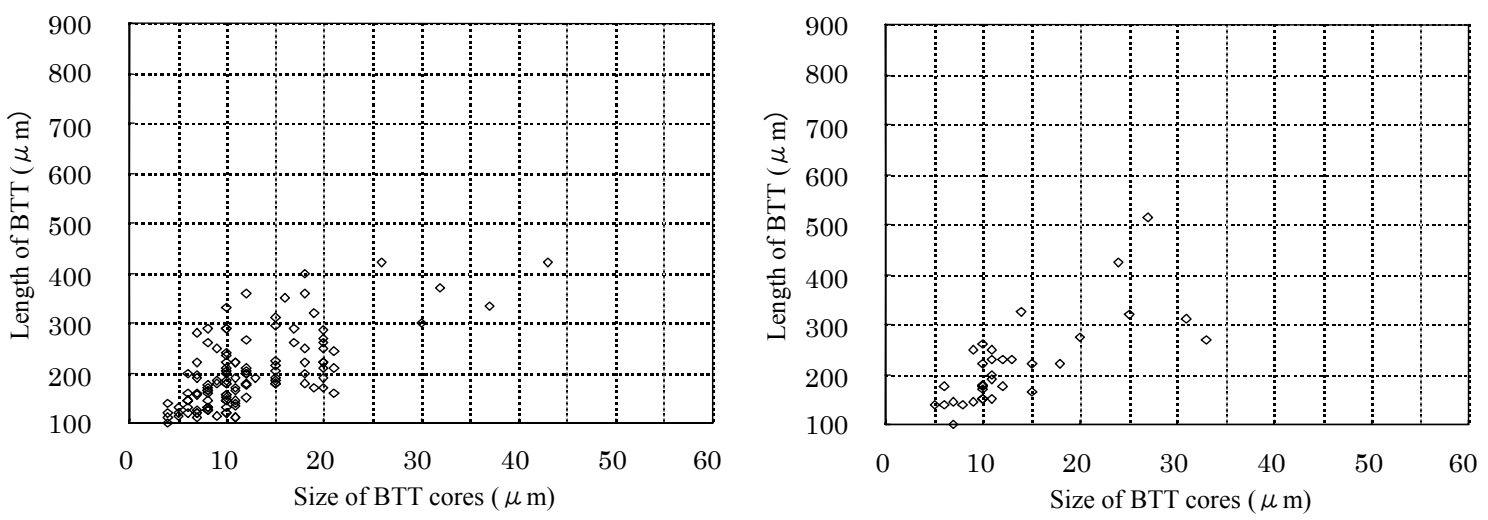

(c) $\mathrm{D}_{2} \mathrm{O}: 10 \mathrm{wt} \%$

(d) $\mathrm{D}_{2} \mathrm{O}: 100 \mathrm{wt} \%$

図 6 重水の濃度別における BTT 発生核の大きさと伸びの関係

Fig. 6. Relation between size of BTT cores and length of BTT in various concentrations of $\mathrm{D}_{2} \mathrm{O}$.

表 4 電解質水溶液を用いた加速劣化試験後の BTT の発生数と最大伸び

Table 4. Number and maximum length of BTT after accelerated aging test using electrolyte solution.

\begin{tabular}{|c|c|c|c|c|c|c|}
\hline \multirow[b]{2}{*}{ Water quality } & \multicolumn{2}{|c|}{ Water content } & \multirow{2}{*}{$\begin{array}{l}\text { Number } \\
\text { of cores } \\
\left(\mathrm{N} / \mathrm{mm}^{3}\right)\end{array}$} & \multicolumn{3}{|c|}{ BTT } \\
\hline & $\begin{array}{l}\text { Before aging } \\
\text { (ppm) }\end{array}$ & $\begin{array}{l}\text { After aging } \\
\text { (ppm) }\end{array}$ & & $\begin{array}{l}\text { Number } \\
(\mathrm{N})\end{array}$ & $\begin{array}{c}\text { Generating } \\
\text { ratio (\%) }\end{array}$ & $\begin{array}{c}\text { Maximum } \\
\text { length }(\mu \mathrm{m})\end{array}$ \\
\hline Demineralized water $\left(\mathrm{D}_{2} \mathrm{O}: 0 \mathrm{wt} \%\right)$ & \multirow{5}{*}{$<5$} & 37 & \multirow{5}{*}{$\sim 11.3$} & 100 & 8.7 & 820 \\
\hline $0.2 \mathrm{~mol} / \mathrm{kg} \quad \mathrm{NaCl}$ solution & & 60 & & 28 & 2.4 & 260 \\
\hline $2.0 \mathrm{~mol} / \mathrm{kg} \quad \mathrm{NaCl}$ solution & & 53 & & 42 & 3.6 & 530 \\
\hline $2.0 \mathrm{~mol} / \mathrm{kg} \quad \mathrm{CaCl}_{2}$ solution & & 37 & & 9 & 0.8 & 190 \\
\hline $4.0 \mathrm{~mol} / \mathrm{kg} \quad \mathrm{CaCl}_{2}$ solution & & 23 & & 0 & 0 & - \\
\hline
\end{tabular}

Volume of observation : $1020 \mathrm{~mm}^{3}$, Length of observation on BTT and VT : $\geqq 100 \mu \mathrm{m}$

同位体効果は同位体の質量差に起因する物理的あるいは 化学的な効果を指すが，この H と D の質量差が BTT の発 生・進展環境に何らかのネガティブな影響を及ぼしたのは 間違いない。そこで表 3 に，軽水と重水の代表的な化学的 性質を比較して示した。誘電率は両者ほぼ等しいものの, 塩の溶解度やイオンの移動度は, 軽水と比べて重水のほう が 15〜20\%程度小さな值となっている。したがって, 重水 中では電解質のイオン解離が起き難く, イオンの運動もや や緩慢になる。これらの性質が BTTの抑制につながった可 能性が考えられるため, 以下では水とイオン解離（生成） の関係に着目して考察した。

\section{〈3·2〉浸漬水中のイオン解離 今回の実験では浸漬}

水中の不純物（イオン）がもともと少ないため, イオン解 離の影響を直接評価することは難しい。そこで，所定の濃 度 $(0.2 \mathrm{~mol} / \mathrm{kg}, 2.0 \mathrm{~mol} / \mathrm{kg}$ および $4.0 \mathrm{~mol} / \mathrm{kg}$ の 3 水準 $)$ に調整した $\mathrm{NaCl}$ 水溶液と $\mathrm{CaCl}_{2}$ 水溶液（いずれも溶媒は イオン交換水を使用）を浸漬水として用い，前述と同一の 課電条件にて試料に BTT を発生させて, イオン解離の影響 を評価した。表 4 に BTT の観察結果を示す。表中の水道水 については, 参考值として文献 $(7)$ より引用した（実験条件 等は全て同じである)。表 4 から BTT の発生・進展は概ね, イオン交換水 $>$ 水道水 $>\mathrm{NaCl}$ 水溶液 $>\mathrm{CaCl}_{2}$ 水溶液 の順で顕著であり,さらに $\mathrm{NaCl}$ 水溶液および $\mathrm{CaCl}_{2}$ 水溶 液においては, いずれも濃度が低いほど顕著である。総じ 


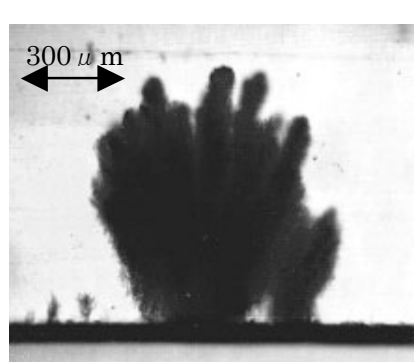

(a) $0.2 \mathrm{M} \mathrm{NaCl}$ solution

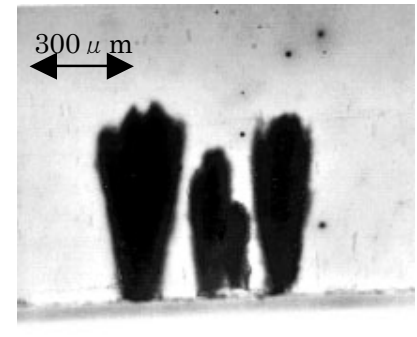

(b) $0.2 \mathrm{M} \mathrm{CaCl}_{2}$ solution
図 7 界面トリーの一例

Fig. 7. A sample of vented tree.

て電解質（イオン）の濃度が高いほど BTT の発生・進展が 抑制されていることから，重水の BTT 抑制効果は，少なく とも浸漬水中のイオン解離の減少に起因したものではない と推察される。他方, 試料中の水分量に関しては, 電解質 の濃度が高いほど減少しているが, 前述のようにこの程度 の変化であれば影響はないと考えられる。

ここで, $\mathrm{NaCl}$ 水溶液および $\mathrm{CaCl}_{2}$ 水溶液では, 図 7 に示 すようなイオン交換水や水道水では観察されなかった界面 トリー (vented tree;VT) が多数観察されたことを付け加え ておく。発生起点となる界面不整や微小突起部からのイオ ンの大量供給は, 界面トリーの発生・進展を顕著に促進す ることが改めて確認できた。

〈3.3〉発生核とイオン生成ここれまでの考察から, 重水の BTT 抑制効果は浸漬水中ではなく, 主として試料中 で発現する水素の同位体効果に起因していると推察され る。前述のように界面トリーにおいては, 発生起点となる 界面不整や微小突起部からのイオンの大量供給は重要な促 進条件となる。このことから BTTにおいては, XLPE 外部

(浸漬水) からのイオン供給のみならず，発生核となる異 物からの直接的なイオン供給も発生・進展に深く関与して いると思われる。特に今回の実験では発生核が銅粉である ため, XLPE との界面に水分が凝集・液化するとイオン化 （溶出）する可能性が高い。この機構はデンドライトを形 成するようなマイグレーションの類ではなく，例えば銅配 管で生じる銅イオンの溶出 (一般的に数 ppm 以下とされる) と同じであろう。そのためXLPE との界面に重水が凝集・ 液化した場合には，銅粉のイオン化が阻害され BTT が抑制 されると考えられる。このモデルはボイドやブラック（炭 素粉)，アンバー（焼け樹脂）といったイオン化し難い非金 属性の発生核との比較実験により, ある程度の検証は可能 であろう。ただし，BTT 発生核の影響に関しては後述する ように局所的な環境の違いも考慮する必要があり, 実験デ ータの単純な比較のみでは不十分である。

金属イオンの溶出に関しては, イオン化傾向がより上位 にあるイオンが拡散してくる場合にも，類似した BTT 抑制 効果が現れると考えられる。例えば浸漬水から試料中に拡 散してきたであろう $\mathrm{Ca}^{2+}$ および $\mathrm{Na}^{+}$に着目すると, それら のイオン化傾向は $\mathrm{Ca}>\mathrm{Na}>>\mathrm{Cu}$ の順であるから, $\mathrm{Ca}^{2+}$ のほうが $\mathrm{Cu}$ のイオン化を阻害しやすい。実際, $\mathrm{CaCl}_{2}$ 水溶
液のほうが $\mathrm{NaCl}$ 水溶液よりも BTT 抑制効果が顕著に現れ ている。逆に, イオン交換水では BTT の発生・進展が顕著 であるが，これは $\mathrm{Cu}$ のイオン化を阻害する不純物（アルカ リ金属やアルカリ土類金属等）が最も少ないためと考えら れる。概略, $0.2 \mathrm{~mol} / \mathrm{kg}$ の $\mathrm{CaCl}_{2}$ 水溶液または $\mathrm{NaCl}$ 水溶液 における BTT 抑制効果は, 重水 $100 \mathrm{wt} \%$ の場合にほぼ匹敵 する (表 4 参照)。

ところで今回のような密閉系課電では, 浸漬水の蒸発・ 揮散（電解質の濃縮）が起きる開放系課電と比較すると, BTT の発生数が著しく減少する(7)。これは, BTTの発生・ 進展が試料外部すなわち浸漬水のイオン濃度の経時変化に 対して極めて敏感に反応することを示している。したがっ て密閉系課電は, そうした外的環境の変化による影響を受 け難く, 発生核およびその近傍の水分の振る舞いを考察す るのに適した課電方法と言える。なお, 発生核に関しては 近傍の局所電場の大きさのみならず, XLPE 界面との相溶 性等も BTT の発生挙動に大きな影響を及ぼしている可能性 があることから ${ }^{(9)}$, 改めて報告したいと考えている。

$\langle 3 \cdot 4\rangle$ 水トリー現象の本質とイオンの役割 最近, 界面トリーの発生・進展に対する水（溶媒）の主な役割と して, XLPE 中へのイオンの運搬が指摘されているが(10), BTT においても同様の役割があることは容易に類推でき る。さらに今回の実験で観察された重水の BTT 抑制効果を 踏まえると, 水分は微小異物一XLPE 界面におけるイオン の生成（溶出）といった役割も果たしているのは間違いな い。ただし, 絶縁体外部からのイオン供給と比べると, 密 閉系課電の結果が示すように必ずしも効率的とは言えない 面もある。いずれにせよ, イオンが重要な鍵を握っている ことは確かで, この意味では水トリー現象の本質は水では なくイオンにあると考えて良い。最近の著者らの実験では, 水トリー中の無機不純物に関して, 特定の元素の異常な増 減や同位体比の有意な変化が観測されるなど, 奇妙な振る 舞いを示すデータが得られている(11)(12)。イオン（特に金属 イオン）が関与した未知の物理的あるいは電気化学的な反 応によって, 水トリーが発生・進展するモデルが考えられ る。

\section{4. あとがき}

$\mathrm{CV}$ ケーブルの重要な寿命決定因子の一つであるボウ・タ イ状水トリー（BTT）の発生・進展に対する水分の役割に ついて実験的に考察した。今回は, 所定の濃度に調整した 軽水 $\left(\mathrm{H}_{2} \mathrm{O}\right)$ および重水 $\left(\mathrm{D}_{2} \mathrm{O}\right)$ の混合液体に XLPE 試料 を浸漬し, 密閉系課電にて BTT を発生させた。さらに, そ れぞれの夜体が有する化学的性質の違いが BTT の発生によ゙ のような影響を及ぼすかを調査した。実験の結果, 以下の 知見が得られた。

（1） BTT の外観は軽水と重水で特に違いは見られず, 形状に関しては水素の同位体の影響は認められなかった

（2）重水では軽水と比べて BTT の発生数は $1 / 3$ に減少 し，最大伸びも鈍化した 
（3）重水には，BTT の発生・進展を抑制する水素の同 位体効果が認められた

（4）重水の BTT 抑制効果は，BTT の発生核として混入 した銅粉のイオン化（溶出）を阻害することによって発現 していると考えられた

（5） BTT の発生・進展に対する水分の役割として, 絶 縁体外部からのイオン供給の他に, 微小異物一絶縁体界面 におけるイオンの生成（溶出）が考えられた

最後に，本実験でご協力頂いた元タッタ電線株式会社の 伊達＼cjkstart博氏に感謝いたします。

(平成 17 年 9 月 22 日受付，平成 18 年 1 月 27 日再受付)

\section{文献}

（1）烟 良輔：「電力ケーブル技術の変遷」, 電学誌, Vol.121, No.2, pp.123-126 (2001-2)

（2）絶縁材料・インパルストリーイング調查専門委員会:「有機絶縁材料 における水トリーについて(3)-ボウタイ状水トリーー」, 電気学会 技術報告，I 部，No.134 (1982)

(3) T. Hashizume, C. Shinoda, K. Nakamura, M. Hotta, and T. Tani : "Influence of Bow-tie Trees on Residual AC Breakdown Voltage of Dry-Cured XLPE Power Cables under Immersed Accelerated Aging Test", T. IEE Japan, Vol.114-A, No.3, pp.258-266 (1994-3) (in Japanese)

橋詰俊成・篠田千春・中村和成・堀田昌弘・谷 恒夫 :「浸水課電下 における乾式架橋ポリエチレンケーブルの残存破壊電圧特性に及ほ すボウ・タイ状水トリーの影響」, 電学論 A, 114, 3, pp.258-266 (1994-3)

(4) S. Kuma, K. Soma, and H. Sakaguchi : "Generation Mechanism of Bow-tie Trees and Development of their Suppression Method", T. IEE Japan, Vol.103-A, No.10, pp.45-52 (1983-10) (in Japanese) 隈 彰二・杣謙一郎・坂口春典: 「ボウタイ状水卜リーの発生機構と その抑止」, 電学論 A, 103, 10, pp.45-52 (1983-10)

(5) H. Ohno, G. Katsuta, I. Kajiki, K. Kato, Y. Sakaguchi, and G. Tanimoto : "A Study on Electrical Deterioration and Quality Control of XLPE Cable", Proc. 4th Annual Conf. Power \& Energy Society, IEE Japan, No.44 (1993-8) (in Japanese)

大野博伸・勝田銀造 $\cdot$ 加治木勇・加藤賢司・坂口義則 - 谷本 元 : $\lceil\mathrm{CV}$ ケーブルの絶縁劣化と品質管理に関する一考察」, 平成 5 年電 気学会電力・エネルギー部門大会, No.44 (1993-8)

(6) Z. Fan, H. Miyata, I. Fujimoto, and T. Niwa : "Relation between Oxidation Ability of Various Ion and Growth of Water Trees", The Papers of Technical Meeting on Dielectrics and Electrical Insulation, IEE Japan, DEI-97-57 (1997)

(7) T. Kumazawa, W. Nakagawa, and H. Tsurumaru : "Infuluence of Water and Ion Diffusion on Generating and Progress of Bow-tie Tree", IEEJ Trans. FM, Vol.125, No.10, pp.828-834 (2005-10) (in Japanese)

熊澤孝夫・中川 渡・鶴丸秀一:「ボウ・タイ状水トリーの発生・進 展に与える水分とイオン拡散の影響」, 電学論 $\mathrm{A}, 125,10$, pp.828-834 (2005-10)
（8）塚本裕一・近藤光興 - 桜井直行: 「重水濃度測定法一新型転換炉「ふ げん」発電所における管理技術 $2 」$, 動力炬技報, No. 30 , pp.45-52 (1979-5)

(9) T. Kumazawa, H. Date, S. Morinaga, and W. Nakagawa : "Characteristic of Bow-tie Water Tree in XLPE Including Contaminants and Voids (1)", 1998 National Convention Record, IEE Japan, No.343 (1998-3) (in Japanese)

熊澤孝夫・伊達 博・森永清司・中川 渡 :「ボウタイ状水トリーの 特性について (その 1)」, 平成 10 年度電気学会全国大会, No. 343 (1998-3)

(10) Y. Miyashita : "Elucidation for Electro-chemical Degradation of Cross-linked Polyethylene Insulated Power Cable", IEEJ Trans. $F M$, Vol.125-A, No.4, pp.385-391 (2005-4) (in Japanese) 宮下芳次: 「架橋ポリエチレン絶縁ケーブルの電気化学劣化メカニズ 么の解明」, 電学論 A, 125, 4, pp.385-391 (2005-4)

(11) T. Kumazawa. W. Nakagawa, and H. Tsurumaru : "A Syudy on Behavior of Inorganic Impurities in Water-tree", IEEJ Trans. $F M$, Vol.124, No.9, pp.827-836 (2004-9) (in Japanese) 熊澤孝夫・中川 渡・鶴丸秀一: 「水トリー中の無機不純物の挙動に 関する一考察」, 電学論 A, 124, 9, pp.827-836 (2004)

(12) T. Kumazawa. W. Nakagawa, and H. Tsurumaru : "A Syudy on Behavior of Inorganic Impurities in Water-tree", Electrical Engineering in Japan, Vol.153, No.2, pp.1-13 (2005-11)

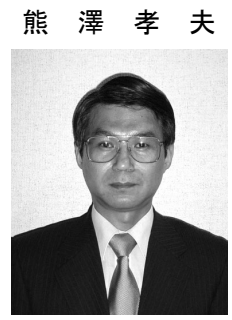

（正員） 1958 年 6 月 26 日生まれ。 1983 年 3 月岐阜大学大学院工学研究科修士課程修了。同 年 4 月中部電力（株）に入社。現在，同社電力 技術研究所にて高分子絶縁材料の劣化様相解 明や電力ケーブル・機器の劣化診断に関する研 究に従事。1995 年 3 月岐阜大学大学院工学研 究科博士後期課程修了。工学博士。日本原子力 学会会員。

中 川 渡 (正員) 1948 年 8 月 10 日生まれ。 1972 年 3

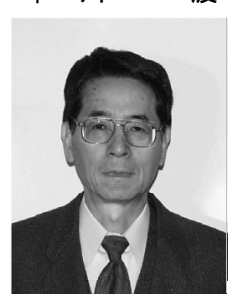
月大阪大学基礎工学部卒業。同年 4 月タッタ電 線（株）に入社。主として，高分子絶縁材料を 用いた電力ケーブルの改良・開発と絶縁劣化に 関する研究に従事。2005 年 4 月より（社）電 線総合技術センターに出向，現在に至る。

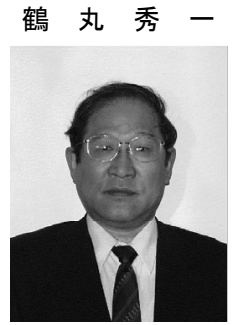

（正員） 1947 年 2 月 2 日生まれ。 1969 年 3 月同志社大学工学部工業化学科卒業。同年 4 月 タッタ電線（株）に入社。主として, 電力ケー ブルの開発改良, 高分子材料の劣化に関する研 究に従事，現在に至る。 